\title{
Integrin Alpha-V
}

National Cancer Institute

\section{Source}

National Cancer Institute. Integrin Alpha-V. NCI Thesaurus. Code C53961.

Integ rin alpha-V (1148 aa, $116 \mathrm{kDa})$ is encoded by the human IT GAV gene. This protein plays a role in cell-matrix adhesion and pathological angiogenesis. 